UDC 005.44-048.58:338.242.4

DOI: $10.15673 /$ fie.v12i1.1673

Nikoliuk 0.

Doctor of Economics, Professor

Department of Management and Logistics

Email: alenavn11@gmail.com

ORCID ID: 0000-0002-1665-0361

\author{
Donets L \\ Ph.D., Associate Professor \\ Department of Marketing, Business and Trade \\ Email: lesia.donets1981@gmail.com \\ ORCID ID: 0000-0001-6113-3702
}

\author{
Klevets M. \\ The student of the fourth grade of Management, Marketing and Logistics Faculty \\ Odessa National Academy of Food Technologies \\ Kanatna str., 112 Odesa, Ukraine, 65039 \\ E-mail: maryaklevets@gmail.com \\ ORCID ID: 0000-0003-0259-4538
}

\title{
REVERSE FORMS OF GLOBALIZATION AND THEIR IMPACT ON THE PUBLIC GOVERNANCE SYSTEM
}

Nowadays, globalization has become one of the most popular concepts of various fields of scientific knowledge. But a unified conceptual system of views on the essence of globalization and the nature of its impact has not yet been established. The polarization of theoretical constructs of globalization today casts doubt on the possibility of forming a coherent theoretical vision of the content of globalization, the patterns of its influence, and the prospects for the development of the world as a whole. The growing interdependence between government and globalization unifies and standardizes the conditions and factors of development of individual countries in the world. It is a kind of indicator of determining the level of sustainability of the development of nation states and, as a conclusion, their potential in facing the challenges of globalization processes. It is these processes that have become the main criterion for the integration of states into relevant global or regional structures in our time. Only a state that has an active system of government, implements its own geopolitical development strategy, maximizes its sovereignty, oriented in the global space, and most importantly, it has effective mechanisms of influence and even management can withstand such a globalization challenge.

Key words: globalization, public administration, alternative to globalization, regionalization, Chineseization, Brazilianization.

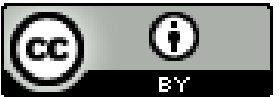

This work is licensed under a Creative Commons Attribution 4.0 International License http://creativecommons.org/licenses/by/4.0/
Statement of the problem and its connection with important scientific and practical tasks. Although Ukraine today expresses its desire for excessive openness to be involved in diverse transnational structures, it still needs to develop effective mechanisms for development and functioning in the context of globalization. It is important to develop a unique national globalization policy that takes into account the correlation of geostrategic forces in the global space and clearly defines Ukraine's place and role in it.

In general, the causes of occurrence speed and scale of global economic crises have called into question not only the idea of globalization as a positive factor in the development of civilization, but also the classic free market strategy in general, forcing politicians, researchers and scientists to reconsider the role of modern functions of states in globalization. processes. Globalization policy should be provided by national advocacy services not by adapting to the needs of a planetary development system, but, to some extent, by declaring and realizing their own nationally regulated position on a global scale.
The analysis of the latest publications on the problem. In the works of scientists (W. Elwood [1], W. Beck [2], G.-P. Martin, H. Schumann [3], G. Kuzmenko [4], O. Karpukhin, E. Makarevich [5], F. Fukuyama [6], V. Mezhuev [8], I. Gryshova, W. Strielkowski [9], S. Lekar, O. Nikoliuk [10], R. Voitovich [11]) the administrative aspects of the formation and implementation of state policy were developed.

In the studies of domestic scientists-economists, devoted to the problems of globalization, its influence on public policy, the state of things in this field is investigated to a greater extent, and to some lesser extent proposals for its improvement are provided. There are now a number of theories in Ukraine that emerged through empirical research on globalization, its multifaceted infinity, modification results, and the possible paths to a largescale negative-global process.

Despite the wide range of areas of study of the features of globalization and the implementation of some measures in public policy, in the works of these scientists the issue of development of strategic guidelines of public 
policy in this area and their effectiveness was not practically reflected.

Forming of the aims of the research. Definition and substantiation of directions of scientific researches in the field of public administration of the processes of European integration of Ukraine in the conditions of globalization.

Giving an account of the main results and their substantiation. Considering this aspect of the problem, it is advisable to proceed from the understanding of "reverse" or theoretically possible forms of globalization, which may be its consequence and ensure the proper development of the world. From a methodological point of view, it is essential to clearly distinguish between American and European approaches to the knowledge of the features and essence of globalization, because there is a fundamental difference that indicates its different functional content. It is also important to set the boundaries of theoretical and political-ideological approaches to understanding alternatives to globalization.

In the current context of social development, the community of extraordinary concentration acquires a clear definition of the path that humanity will take if the previous world order is destroyed, and whether it can find an equivalent alternative to globalization. It is crucial here for the international community to consider whether it is rational to follow the traditional development scenario, or to choose the path to adapt to the new reality. The answer to this question naturally depends on the history, practice and specificity of the policy of the nation state, as well as on how competitive the states of the world are in economic and political terms [1].

Today, the whole world is experiencing a kind of "geopolitical renaissance", which can lead to the emergence of a new style of formation of international relations, which involves the activities of transnational actors (transnational corporations, transnational media and others). The "geopolitical renaissance" points to a particular "erosion" of the nation state, which in the conditions of globalization forfeits a considerable amount of its powers, delegating them to regional and transnational federations.

An alternative to globalization growth could be India, which now has every prospect of becoming an independent and sovereign "geopolitical pole" that will determine the patterns and rules of political and economic development of the world. However, a permissible leader in geopolitical development may be Brazil with its powerful development potential [3].

The above trends confirm the emergence of alternative forms of globalization, which in the future will determine the features and specifics of the development of the modern world.

An important position belongs to regional governments in the context of the development of the modern world. After all, regions, not national states, are the main "actors" of the newly created system of the world order. We are talking about the modern configuration of the world order, within which the nation state in its usual sense loses its personal functional purpose, and instead it is replaced by new "quasi-state structures" that determine the development of the modern world.

The process of regionalization, in its modern form, contradicts the principles of global globalization, which cover the whole world as a whole, unlike regionalization. After all, it leads to the formation of independent regional associations that act as subjects of realization of interests of the territory. The emergence of modern regional associations is accompanied by the emergence of international organizations that open the prospects they need to pursue their respective territorial interests (trade, economic and political).

Of course, the emergence of regionalization refers to the emergence of a global economic system, which blurs the boundaries between sovereign states of the world. At the same time, the most important position belongs to the regulation of trade between those countries of the world, which have initiated the complementarity of economic models with each other. That is, the development of interstate trade relations is one of the prerequisites for the emergence of regionalization in its modern transformation.

Considering the positive aspects of regionalization and its alternative to the processes of globalization, it is advisable to start with the optimality of its implementation. It is quite possible to use the formula of civilizational association, the mechanisms of creation of which are developed in the concept of ethnogenesis of L. Gumilev to the newest algorithms of regionalization. In his view, "from groups of like-minded people consortia form" that is groups of people united by a single historical fate, who eventually either break up or grow into convictions - "groups of people with similar life and family ties" [4].

Based on the information above, regionalization as an alternative form of globalization will lead to the destruction of world governance systems through the formation of appropriate regional entities that will give rise to new forms of government. Regionalization is one way of solving national problems of social development through the creation of equal and equally beneficial forms of interregional interaction, which enables the individual state to bring its interests to compromise or even cooperation. The mechanisms of formation of such parity conditions of interaction are fundamentally different because they are determined by the level of a particular region and its suitable status, which in turn, determines the effectiveness and stability of the relevant regional entity. Accordingly, an important condition for the efficiency of regionalization processes is the level of regional freedom, which in turn determines the relevance of regionalization and the status of the state within the respective regional association.

At the present stage of social development, there is a trend of Chinese pressure on the world space. This gives grounds to speak of sinicization as an reverse form of globalization. Logically, a significant factor in the impact of an individual region (individual national economy) on world development is the financial and political factor. China is no exception. The impact of China on the development of the modern world is obvious. For example, the growth of its economic strength and the level of 
investment overseas, which today amount to more than $\$$ 30 billion. This gives reason to China to become an active subject of the invention of a modern system of international relations today. After all, China was indirectly a passive player in geopolitical processes [6].

The current type of sinicization of social development can also be reflected in China's transition to a policy of multilateral diplomacy, which is possible in the context of globalization's implications. Most tendencies, however, indicate a rather aggressive policy of the present-day Chinese state to pursue its national interests abroad. Similarly, if China had previously favored a policy of prioritizing bilateral relations, it is now in its interest, in particular, to defend the principled position of Chinese business and citizens. China is now multiplying its control potential by raising a rational strategic perspective on the impact on the world, and sometimes in a rather aggressive form. This demonstrates an uncompromisingly new model of China's policy in today's globalized environment, where it is gaining a particularly influential force aimed at the economic and political development of the world's modern world.

However, China's expressive "rigidity" of pursuing its interests within the globalized world is accompanied by rather liberal forms. After all, China is afraid to lose the support and at least the positive support and attitude of the Western world. China aims to achieve global and regional stability in the world. However, Sinicization is not the only alternative for the further development of the modern world. Equally important are the trends of Brazilization, which are taking on new forms of influence on the development of today's global world.

The latest trend in the development of the socioeconomic western world is Brazil and its neoliberal utopia of the "free market". The modernization of the world cannot take place in just one vector of development, be- cause in this connection there is a need to institutionalize different national and regional values systems that struggle to qualify for global resources. This again shows that the whole modern world is not able to choose Americanization or sinicization as an alternative to its development, because there are other leading ideas and directions of development besides them.

The "free market" utopia, as a new tendency of social development, constitutes and defines the features of the "semi-industrial" model of the state with the unstable employment system and working conditions resulting from the legal field. Such a trend is becoming more and more characteristic of states today, even those that belonged to the category of the highly developed and have had an effective employment system so far [7, 6].

This, in terms of and due to the monitoring of the employment system by world experts, is explained by the fact that highly skilled, well paid and exciting work has gradually disappeared in the advanced and highly developed countries of the world. Due to the fact that highly qualified personnel emigrate to another country in the conditions of globalization, because there is an interesting and simultaneously well-paid job for him. That is, today we are talking about the influence of the "new legislators of the modern world", the so-called enclave states, to which Brazil belongs. It is Brazil that produces the new model for the modernization of the modern world, but such a model poses significant risks because it "exacerbates social injustice and destroys already fragile social balance in the West" [9].

Famous researchers of globalization U. Beck, G.-N. Martin, X. Schumann predict the destruction of the middle class and the "Brazilization" of Europe, and even the world. From their point of view, "Brazilization" is a transition to a fundamentally different civilization of the "golden billion" or "society 20:80" (Fig. 1) [2].

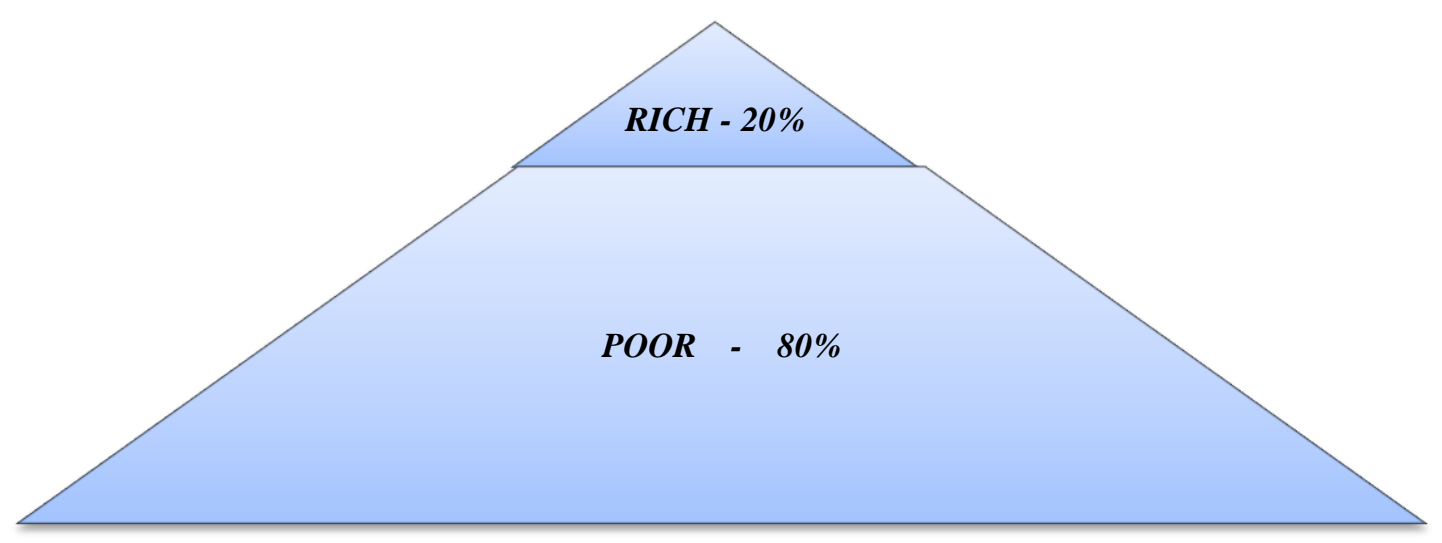

Fig. 1. Society 20:80 [2]

Most of the countries in the world are characterized by certain patterns of globalization development, to which we refer, in particular, to Brazilization, and it symbolizes the economic formula of development of the modern world, taking into account probable risks and challenges of the conditions of globalization. Globalization and its reverse forms naturally create globalization challenges that can lead to global problems in different spheres of social life, the solution of which determines by the content of the policies of modern nation states. That is why the subject of the analysis in the framework of further research is the global challenges of social development and ways of solving them [11].

Conclusions and prospects of the further investigations. Getting out of the economic recession and improving the economic situation in a globalized world is 
a major policy issue. Increasing globalization and interconnectivity between countries creates spatial and temporal dependencies that will affect the production process of each country. We are expanding our existing methodological tools - a reliable boundary in non-parametric placement models.

By controlling multilevel factors in the regression of savings and investment, we effectively isolate the impact of exogenously increased savings on investment, regardless of the nature of the common sources. The globalization of the world economy is one of the new and extremely relevant trends in the development of the modern economic system. Its significance is that the globalization of planetary processes has a significant impact on the technological, socio-economic and environmental development of the world community. Accounting for them is not only practical, but also of great methodological importance, because it allows you to highlight the most common issues of human progress, determine the totality of the main challenges globalization for both countries, industries, firms and regions.

The contradictions of the reproduction of the global system of the world economy are in that fact that very often it is subordinated not only to the interests of the world community, as the interests of the business elite. It is carried out in the conditions of uneven distribution of natural and climatic and labor resources, wealth, dependence of the economy on politics, simplified ideas of people about regularities of planetary economy functioning. However, this does not mean that the global reproduction of the world economy has nothing to do with the past: the interest of all segments of society, of the whole system of socio-economic institutions in maximizing profits remains. At the same time, new goals and objectives emerge, new principles of social and environmental policy, are approved social confrontation reduces.

The need to introduce and develop effective mechanisms for integrating Ukraine into the world community is first and foremost linked to a deep understanding of the country's geopolitical progressive strategy in the context of globalization, and most importantly to answering the question of how our country should develop and what is its importance in the current globalization processes. Whether Ukraine is a full-fledged subject of such processes, or whether it remains an independent appendage to a certain integral synthesis of states where it should humbly play not by its own, but by someone else's rules of the game.

\section{References}

1. Elvud, U. (2013). Globalizatsiya. (A. Zaharova, Trans.). Moscow: Knizhnyiy Klub «Knigovek».

2. Bek, U. (2001). Chto takoe globalizatsiya? Oshibki globalizma - otvetyi na globalizatsiyu. (A. Grigoreva \& V. Sedelnikova, Trans.). Moscow: Progress-Traditsiya.

3. Martin, G. P., \& Shumann, H. (2001). Zapadnaya globalizatsiya: Ataka na protsvetanie i demokratiyu. Moscow: Izdatelstvo doma "Alpina."

4. Kuzmenko, H. (2006). Hlobalizatsiia kultury: vtraty i prydbannia. Sotsialna Polityka i Sotsiolohiia, (4), 2425.

5. Karpukhin, O. I., \& Makarevych, E. F. (2006). Natsionalna kultura - osnova natsionalnoi identychnosti v hlobalizovanomu sviti. Sotsialno-Humanitarni Znannia, (2), 32-33.

6. Fukuyama, F. (2004). Velikiy razryiv. Moscow: AST.

7. Andreychuk, N. V. (2010). Fenomen globalizatsii i problema kulturnogo raznoobraziya sotsiuma. Vestnik Rossiyskogo Gosudarstvennogo Universiteta Im. I. Kanta, (6), 57-68.

8. Mezhuiev, V. M. (1996). Mizh mynulym i maibutnim. Moscow: IF RAN.

9. Gryshova, I., Strielkowski, W., \& Kalyugina, S. (2017). Modern Technologies in Public Administration Management: A Comparison of Estonia, India and United Kingdom. Administratie Si Management Public, (28), 174185.

10. Lekar, S., Shumeiko, D., Lagodiienko, V., Nemchenko, V., Nikoliuk, O., \& Martynyuk, O. (2019). The Use of Bayesian Networks in Public Administration of the Economy. Blue Eyes Intelligence Engineering \& Sciences Publication, 8(5), 1419-1421.

11. Voitovych, R. V. (2007). Vplyv hlobalizatsii na systemu derzhavnoho upravlinnia (teoretykometodolohichnyi analiz). (V. M. Kniaziev, Ed.). Kyiv: Vyd-vo NADU.

12. Tetszian, Khou., \& Hryshova, I. (2018). Konkurentni viiny biznesu v umovakh strimkoho rozvytku tsyfrovoi ekonomiky ta finansovoho inzhynirynhu. In Tsyfrova ekonomika: trendy ta perspektyvy (pp. 120-122). Ternopil: Osadtsa Yu. V.

13. Gryshova, I., Petrova, M., Tepavicharova, M., Diachenko, A. P., \& Gutsul, T. (2019). A model for selection of a management team to ensure the sustainability and development of the business organizations, Entrepreneurship and Sustainability Issues, 7(1), 690-703. doi: 10.9770/jesi.2019.7.1(49). 
Николюк Е.В.

доктор экономических наук, профеессор кафедра менеджмента и логистики

Email: alenavn11@gmail.com ORCID ID: 0000-0002-1665-0361
Донец А.Я.

кандидат технических наук, доцент кафедра маркетинга, предпринимательства и торговли Email: lesia.donets1981@gmail.com ORCID ID: 0000-0001-6113-3702

Клевец М.В.

студентка 4 курса фракультета менеджмента, маркетинга и логистики Одесская национальная академия пищевых технологий ул. Канатная, 112, г. Одесса, Украина, 65039

E-mail: maryaklevets@gmail.com ORCID ID: 0000-0003-0259-4538

\section{ОБРАТНЫЕ ФОРМЫ ГЛОБАЛИЗАЦИИ И ИХ ВЛИЯНИЕ НА СИСТЕМУ ГОСУДАРСТВЕННОГО УПРАВЛЕНИЯ}

В наше время глобализация уже стала одним из самых популярных понятий различных сфер научного знания. Но до сих пор не сформирована единая концептуальная система взглядов на тему сущности глобализации и не определен характер ее воздействия. На сегодня поляризация теоретических конструкций глобализации ставит под сомнение возможность формирования общего и целостного теоретического видения полноты содержания глобализации, закономерностей ее влияния и возможностей развития в мировом масштабе в целом.

Глобализация основывается, прежде всего, на взаимосвязанности институтов, населения и отдельных людей и играет все большую роль в жизни людей. Высшая экономическая глобализация подчеркивает рыночной политике, делает правительство более прозрачным и подотчетным и создает лучшие соблюдения глобальных стандартов управления. В то же время, высшая социальная глобализация, что приводит к большему обмена идеями и информацией, а также культурной интеграции, может сделать население более осведомленным о международных норм, может повысить свободу слова с помощью построения сети и обмена идеями.

Глобализация общества - противоречивый процесс, здесь наблюдается как интеграция, так и деинтеграции, как использование традиционных источников энергии факторов, так и новых методов и форм борьбы, в том числе и таких острых, как борьба за выживание. Будущее глобализации мировой экономики видится в глобализации всех сфер жизни общества, всех фракторов, социальных слоев, результатов, пропорций воспроизводства, улучшение инвестиционных и инновационных процессов, формирование нового качества жизни и поведения людей, создании институтов и механизмов международной интеграции.

Ключевые слова: глобализация, государственное управление, альтернатива глобализации, регионализация, китаизация, бразилиация.

Ніколюк О.В.

доктор економічних наук, професор кафедра менеджменту та логістики

Email: alenavn11@gmail.com ORCID ID: 0000-0002-1665-0361
Донець О.Я.

кандидат технічних наук, доцент кафедра маркетингу, підприємництва і торгівлі

Email: lesia.donets1981@gmail.com

ORCID ID: 0000-0001-6113-3702

Клевець М.В.

студентка 4 курсу факультету менеджменту, маркетингу та логістики

Одеська національна академія харчових технологій

вул. Канатна 112, м. Одеса, Україна, 65039

E-mail: maryaklevets@gmail.com

ORCID ID: 0000-0003-0259-4538

\section{ОБЕРНЕНІ ФОРМИ ГЛОБАЛІЗАЦІЇ ТА ЇХНІЙ ВПЛИВ НА СИСТЕМУ ДЕРЖАВНОГО УПРАВЛІННЯ}

У наш час глобалізація вже стала одним із найбільш популярних понять різноманітних сфер наукового знання. Але досі не сформована єдина концептуальна система поглядів на тему сутності глобалізації та не визначений характер її впливу. На сьогодні поляризація теоретичних конструкцій 
глобалізації ставить під сумнів змогу формування загального й цілісного теоретичного бачення повноти змісту глобалізації, закономірностей її впливу та можливостей розвитку в світовому масштабі в цілому.

Глобалізація ґрунтується насамперед на взаємопов'язаності інститутів, населення та окремих людей і відіграє дедалі більшу роль у житті людей. Вища економічна глобалізація наголошує на ринковій політиці, робить уряд більш прозорим та підзвітним та створює кращі дотримання глобальних стандартів управління. У той же час, вища соціальна глобалізація, що приводить до більшого обміну ідеями та інформацією, а також культурної інтеграції, може зробити населення більш обізнаним про міжнародні норми, може підвищити свободу вираження поглядів за допомогою побудови мережі та обміну ідеями.

Глобалізація суспільства - суперечливий процес, тут спостерігається як інтеграція, так і деінтеграції, як використання традиційних джерел енергії, чинників, так і нових методів і фрорм боротьби, в тому числі і таких гострих, як боротьба за виживання. Майбутнє глобалізації світової економіки бачиться в глобалізації всіх сфер життя суспільства, всіх факторів, соціальних верств, результатів, пропорцій відтворення, поліпшення інвестиційних та інноваційних процесів, формування нової якості життя і поведінки людей, створенні інститутів і механізмів міжнародної інтеграції.

Ключові слова: глобалізація, державне управління, альтернатива глобалізації, регіоналізація, китаїзація, бразиліація

\section{Література}

1. Элвуд У. Глобализация / Элвуд У.; пер. с англ. А. Захарова. М.: Книжный Клуб «Книговек», 2013.

$208 \mathrm{c}$.

2. Бек У. Что такое глобализация? Ошибки глобализма - ответы на гло-бализацию / Бек У.; пер. с нем. А. Григорьева и В. Седельникова. М.: Прогресс-Традиция, 2001. 304 с.

3. Мартин Г.-П., Шуманн Х. Западная глобализация: Атака на процве-тание и демократию / Мартин Г.П., Шуманн Х.; пер. с нем. М.: Изд-водома “Альпина”, 2001. 330 с.

4. Кузьменко Г. Глобалізація культури: втрати і придбання // Соціальна політика і соціологія. 2006. № 4. C. $24-25$

5. Карпухін О. І., Макаревич Е. Ф. Національна культура - основа національної ідентичності в глобалізованому світі // Соціально-гуманітарні знання. 2006. № 2. С. 32-33

6. Фукуяма Ф. Великий разрыв. М.: АСТ, 2004. 370 с.

7. Андрейчук Н. В. Феномен глобализации и проблема культурного разнообразия социума // Вестник Российского государственного университета им. И. Канта. 2010. № 6. С. 57-68.

8. Межуєв В. М. Між минулим і майбутнім. Обр. соц.-філос. публіцистика. М.: ІФ РАН. 1996. С. 6.

9. Gryshova I., Strielkowski W., Kalyugina S. Modern Technologies in Public Administration Management: A Comparison of Estonia, India and United Kingdom // Administratie si Management Public. 2017. vol. 28. P.174-185

10. Lekar S., Shumeiko D., Lagodiienko V., Nemchenko V., Nikoliuk O., Martynyuk O. The Use of Bayesian Networks in Public Administration of the Economy // Blue Eyes Intelligence Engineering \& Sciences Publication. 2019. Vol. 8, iss. 5. June 2019. P. 1419-1421

11. Войтович Р.В. Вплив глобалізації на систему державного управління (теоретико-методологічний аналіз): Монографія / За заг. ред. д-ра філос. наук, проф. В.М.Князєва. К.: Вид-во НАДУ, 2007. 680 с.

12. Хоу Тецзянь, Гришова I. Конкурентні війни бізнесу в умовах стрімкого розвитку цифрової економіки та фінансового інжинірингу. Цифрова економіка: тренди та перспективи: матеріали міжнарод. наук.-практ. конф., Тернопіль, 25 жовтня 2018 р. Тернопіль: Осадча Ю.В., 2018. С.120-122

13. Gryshova I., Petrova M., Tepavicharova M., Diachenko A. P., Gutsul T. A model for selection of a management team to ensure the sustainability and development of the business organizations // Entrepreneurship and Sustainability. 2019. Issues 7(1). P. 690-703. doi: 10.9770/jesi.2019.7.1(49)

Стаття надійшла 26.01.2020

Стаття прийнята до друку 9.02.2020

Доступно в мережі Internet 31.03.20

Цитування згідно ДСТУ 8302:2015

Nikoliuk O., Donets L., Klevets M. Reversed forms of globalization and their impact on the system of public administration // Food Industry Economics. 2020. Vol.12, Issue 1. P. 95-100. doi: 10.15673/fie.v12i1.1673

Cite as APA style citation

Nikoliuk, O., Donets, L., \& Klevets, M. (2020). Reverse forms of globalization and their impact on the public governance system. Food Industry Economics, 12(1), 95-100. doi: 10.15673/fie.v12i1.1673 